\title{
Relationship among Economic Growth, Internet Usage and Publication Productivity: Comparison among ASEAN and World's Best Countries
}

\author{
Hossein Gholizadeh ${ }^{1}$, Hadi Salehi ${ }^{2}$, Mohamed Amin Embi ${ }^{3}$, Mahmoud Danaee ${ }^{4}$, Seyed Mohammad Motahar ${ }^{5}$, \\ Nader Ale Ebrahim ${ }^{6}$, Farid Habibi Tanha ${ }^{7} \&$ Noor Azuan Abu Osman ${ }^{1}$ \\ ${ }^{1}$ Department of Biomedical Engineering, Faculty of Engineering, University of Malaya, 50603 Kuala Lumpur, \\ Malaysia \\ ${ }^{2}$ Faculty of Literature and Humanities, Najafabad Branch, Islamic Azad University, Najafabad, Isfahan, Iran \\ ${ }^{3}$ Faculty of Education, Universiti Kebangsaan Malaysia, Bangi, 43600, Malaysia \\ ${ }^{4}$ Faculty of Agriculture, Roudehen Branch, Islamic Azad University, Roudehen, Iran \\ ${ }^{5}$ Faculty of Information Science and Technology,Universiti Kebangsaan Malaysia, Bangi, 43600, Malaysia \\ ${ }^{6}$ Research Support Unit, Centre of Research Services, Institute of Research Management and Monitoring (IPPP), \\ University of Malaya, Malaysia \\ ${ }^{7}$ Department of Financial Sciences, University of Economic Sciences, Tehran, 1593656311, Iran \\ Correspondence: Hadi Salehi, Faculty of Literature and Humanities, Najafabad Branch, Islamic Azad University, \\ Najafabad, Isfahan, Iran. Tel: 98-913-104-1419. E-mail: hadisalehi1358@yahoo.com
}

Received: January 5, 2014

Accepted: February 7, $2014 \quad$ Online Published: March 14, 2014

doi:10.5539/mas.v8n2p160

URL: http://dx.doi.org/10.5539/mas.v8n2p160

\begin{abstract}
Publication productivity, as measured by the number of papers, has been regarded as one of the main indicators of reputation of countries and institutions. Nevertheless, the relationship among research publications, economic growth and World Wide Web in ASEAN countries is still unclear. The main intention of this study was to identify publication productivity among ASEAN and the world's top ten countries in the last 16 years (1996-2011). This study also aimed at finding the relationship among publication, gross domestic product (GDP) and internet usage. Furthermore, the publication trend in the 10 first Malaysian universities was evaluated for the same periods. Scopus database was used to find the overall documents, overall citations, citations per document and international collaboration from 1996 to 2011 for each country. The World Bank database (World Data Bank) was used to collect the data for GDP and the number of internet users. Moreover, to evaluate 10 top Malaysian universities, the number of published articles, conferences, reviews, and letters for the same periods was collected. The results of this study showed significant differences among ASEAN and top 10 countries regarding publication productivity. Moreover, a positive and significant relationship was observed between indices, GDP and internet usage for these countries. Surprisingly, international collaboration had a significant and negative relationship with economic growth. Malaysia had fewer citations per document (7.64) and international collaboration (36.9\%) among ASEAN countries. In conclusion, international collaboration between academic institutes and researchers is influenced by economic growth and access to internet in the countries. Furthermore, publication trends in ASEAN countries are promising. However, policy makers and science managers should try to find different ways to increase the quality of the research publication and to raise citation per document.
\end{abstract}

Keywords: ASEAN countries, publication productivity, citation, internet user, collaboration, economic growth

\section{Introduction}

The Association of Southeast Asian Nations, a geo-political and economic organization including ten countries located in Southeast Asia, was formed on 8 August 1967 by Indonesia, Malaysia, the Philippines, Singapore and Thailand. Since then, the membership has expanded to include Brunei, Burma (Myanmar), Cambodia, Laos, and Vietnam. One of the main aims of this association is accelerating economic growth (Sarel, 1997). The main tool for measuring a country's economy is Gross domestic product (GDP) that is the market value of all officially recognized final goods and services produced within a country in a given period of time. 
Based on the literature, there is a relationship between economic growth and education and research publication. However, this relationship has not been well supported by realistic evidence (Jin \& Jin, 2013; Nelson \& Phelps, 1966; Lucas, 1988; Becker, 2009; Romer, 1990). The Researches by Mankiw et al. (1992) and Barro (1991) showed positive and significant effects of education on economic growth (Mankive et al., 1992; Barro, 1991). While the study by Bils and Klenow (2000) showed a possibility of reverse relationship between economic growth and education (Bils \& Klenow, 2000). Moreover, in a recent research study, Jin and Jin (2013) indicated that publication productivity in different fields has dissimilar effects on economic growth. For instance, engineering and science have positive influences on economic growth in comparison with publication output in the field of social sciences (J. Jin \& L. Jin, 2013). These days, publication productivity is a main task for researchers and students than in the past decades and the results of research should benefit the community (Zain et al., 2009). Based on new developmental principles, the number of knowledgeable employees could be increased by education (J. Jin \& L. Jin, 2013). In addition, educated human resource would help the economy of the countries to grow faster. Moreover, it is widely observed that the world's top productive research universities are in the highly developed countries such as the United States, the United Kingdom and Canada et al.

Publication count is an indicator of research productivity and used to rank countries and universities (Liu \& Cheng, 2005; Meho \& Spurgin, 2005; Narin \& Hamilton, 1996; Toutkoushian et al., 2003; Yazit \& Zainab, 2007) It can also be used to determine authors' productivity or the publication productivity of research groups (Liu \& Cheng, 2005; Hart, 2000; Uzun, 2002; Gu \& Zainab, 2001; Fox, 1983). The number of citations of previously published works is an indicator of its subsequent recognition and impact in a field of study. Reviewing articles that are frequently cited can provide information about the dominant areas of a discipline and also highlight the growth of particular fields. Furthermore, top-cited articles are often written by recognized experts who can offer insights into future directions of the discipline (Joynt \& Leonard, 1980; Kelly et al., 2010; Lefaivre \& O'Brien, 2011; Ponce \& Lozano, 2010).

Science Citation Index appeared in 1961 (following that, the Social Sciences Index was formulated in 1966). Using this index, it has been possible to answer questions such as "who publishes more articles" and "whose articles are being cited more often?" (Bar-Ilan, 2008; Heeks \& Bailur, 2007; Meho \& Yang, 2007). Hirsch developed the H-index (proposed by Jorge E. Hirsch, a physicist at UCSD, in 2005) as an alternative to traditional bibliometric measures. The H-index is a single bibliometric indicator that combines measures of productivity and impact into one. Hirsch argued that this combination reflects the impact of a publication on the corresponding scientific community (Braun et al., 2006; Schubert \& Glänzel, 2007). H-index retrieved by citation indexes (Scopus, Google scholar, and Web of Science) is used to measure the scientific performance and the research impact studies based on the number of publications and citations of a scientist. It is also easily available and may be used for performance measures of scientists and for recruitment decisions (Aghaei et al., 2013; Ale Ebrahim et al., 2013; Brown \& Gardner, 1985; Fooladi et al., 2013).

In this study, we used the human development index (HDI) to find the top ten countries around the world. HDI is a composite statistic used to rank countries according to their development levels from "very high" to "low". Countries are placed based on life expectancy, education, living standard, child welfare, health care, economic welfare, and population's happiness.

The main purpose of this study was to compare publication productivity among ASEAN and the world's top ten countries from 1996 to 2011. In addition, we intended to find the relationship among publication productivity, gross domestic product (current US\$), and internet usage. Finally, we aimed to investigate the publication trend of the 10 first Malaysian universities in the same periods. In this study, Scopus database (WWW.SCIMAGOJR.COM) was used since it is a primary full-text scientific database and offers about $20 \%$ more coverage than Web of Science (Anad \& Sen, 1994).

We hypothesized publications of academic papers as the research outputs have positive relationship with economic growth and the number of people with access to the worldwide network. Also, there is a significant difference between ASEAN publication productivity and the world's top ten countries.

\section{Method}

To identify publication productivity among ASEAN and the world's top ten countries, Scopus database (SCImago) was used to compare overall documents and citations, cited documents, un-cited documents, self-citations, citations per document and international collaboration from 1996 to 2011. Moreover, the World Bank database (World Data Bank) was used to collect data for GDP and the number of internet users in these countries.

To find the top ten countries around the world, we used the human development index (HDI) (Anad \& Sen, 
1994). Moreover, to find the 10 first universities in Malaysia, we used the number of publications in Scopus database. Furthermore, to evaluate these universities, the number of published articles, conferences, reviews, and letters for the same periods was collected (1996-2011).

\subsection{Data Analysis}

Prior to data analysis, normality test was done for the obtained data. The normality test revealed that all variables were not distributed normally. So, to answer the research questions, non parametric test was used. To evaluate the relationship among related items of publication, GDP and Internet usage, Spearman correlation coefficient test was applied. Moreover, to compare ASEAN countries with the top ten countries, Mann-Whitney U test was used. For evaluating the differences in number of documents, citations, self-citations, and citations per document among ASEAN countries, Kruskal-Wallis test was applied. The Kruskal-Wallis test is a nonparametric test that compares three or more unmatched groups and it is an extension of the Mann-Whitney $U$ test to allow the comparison of more than two independent groups.

\section{Results}

Based on human development index (HDI), the top ten countries around the world are listed as follow: Norway, Australia, USA, The Netherlands, Germany, New Zealand, Ireland, Sweden, Switzerland, and Japan.

Table 1. Comparison between ASEAN countries and the 10 first countries around the world (publication productivity and country ranking)

\begin{tabular}{ccccc}
\hline \multirow{2}{*}{ Country } & Overall Documents & \multicolumn{2}{c}{ Country ranking* } \\
\cline { 3 - 5 } & (1996_2011) in Scopus & publication & H-Index \\
\hline \multirow{3}{*}{ ASEAN } & 1064 & 133 & 140 \\
& Cambodia & 1296 & 128 & 112 \\
& Indonesia & 16139 & 63 & 57 \\
& Laos & 853 & 141 & 135 \\
& Malaysia & 75530 & 42 & 54 \\
& Myanmar & 906 & 139 & 146 \\
& Philippines & 11326 & 70 & 56 \\
& Singapore & 126881 & 32 & 30 \\
& Thailand & 69637 & 43 & 39 \\
& Vietnam & 13172 & 67 & 21 \\
\hline \multirow{3}{*}{ TOP } & Norway & 141143 & 31 & 11 \\
TEN & Australia & 592533 & 11 & 80 \\
& USA & 6149455 & 1 & 3 \\
& Netherland & 487784 & 14 & 26 \\
& Germany & 1581429 & 5 & 27 \\
& New Zealand & 114495 & 34 & 10 \\
& Ireland & 91125 & 39 & 9 \\
\hline
\end{tabular}

* based on 238 countries in the world. 
Table 2. Kruskal Wallis test

\begin{tabular}{|c|c|c|c|c|}
\hline ASEAN countries & Documents (Mean) & SD & Chi square* & p.value \\
\hline Brunei & 66.5 & 32.26 & \multirow{10}{*}{138} & \multirow{10}{*}{$<0.01$} \\
\hline Cambodia & 81 & 64.46 & & \\
\hline Indonesia & 1008.688 & 663.05 & & \\
\hline Laos & 53.3125 & 45.95 & & \\
\hline Malaysia & 4720.625 & 5443.05 & & \\
\hline Myanmar & 56.625 & 41.21 & & \\
\hline Philippines & 707.875 & 283.60 & & \\
\hline Singapore & 7930.063 & 3940.70 & & \\
\hline Thailand & 4352.313 & 2963.70 & & \\
\hline Vietnam & 823.25 & 609.77 & & \\
\hline ASEAN countries & Overall Citation (Mean) & SD & Chi square* & p.value \\
\hline Brunei & 484.0625 & 194.40 & \multirow{10}{*}{140.628} & \multirow{10}{*}{$<0.01$} \\
\hline Cambodia & 801.1875 & 614.26 & & \\
\hline Indonesia & 7406.875 & 2823.18 & & \\
\hline Laos & 478.1875 & 400.11 & & \\
\hline Malaysia & 17601.19 & 5917.94 & & \\
\hline Myanmar & 428.0625 & 245.58 & & \\
\hline Philippines & 7586.875 & 2320.56 & & \\
\hline Singapore & 83167.75 & 32859.46 & & \\
\hline Thailand & 33060.56 & 14704.18 & & \\
\hline Vietnam & 6725.25 & 2789.02 & & \\
\hline ASEAN countries & Self-citation (Mean) & SD & Chi square* & p.value \\
\hline Brunei & 43.4375 & 19.69 & \multirow{10}{*}{142.822} & \multirow{10}{*}{$<0.01$} \\
\hline Cambodia & 88.0625 & 72.82 & & \\
\hline Indonesia & 857.4375 & 223.05 & & \\
\hline Laos & 64.875 & 50.88 & & \\
\hline Malaysia & 4345.5625 & 2483.06 & & \\
\hline Myanmar & 33.625 & 18.62 & & \\
\hline Philippines & 866.0625 & 240.79 & & \\
\hline Singapore & 11939.563 & 4584.45 & & \\
\hline Thailand & 5831.5 & 2407.33 & & \\
\hline Vietnam & 789.25 & 394.57 & & \\
\hline ASEAN countries & $\begin{array}{c}\text { Citation per document } \\
\text { (Mean) }\end{array}$ & SD & Chi square* & p.value \\
\hline Brunei & 9.5081 & 5.37 & \multirow{10}{*}{13.099} & \multirow{10}{*}{$<0.01$} \\
\hline Cambodia & 12.2075 & 6.05 & & \\
\hline Indonesia & 10.8456 & 5.18 & & \\
\hline Laos & 11.8269 & 5.86 & & \\
\hline Malaysia & 7.64 & 3.98 & & \\
\hline Myanmar & 11.5994 & 6.61 & & \\
\hline Philippines & 12.9463 & 6.20 & & \\
\hline Singapore & 12.5063 & 5.02 & & \\
\hline Thailand & 10.6606 & 4.97 & & \\
\hline Vietnam & 11.755 & 5.75 & & \\
\hline
\end{tabular}

To investigate the differences among ASEAN countries, Kruskal Wallis test was applied. The results for all these indices showed that there were significant differences among these countries. 
As Tables 1 and 2 show, Singapore had the highest publications (126881 documents) and Laos had the lowest publications (853 documents) among ASEAN countries, while Malaysia ranking (with 75530 documents) was the second and the forty second among ASEAN and all the world countries, respectively (based on 238 countries in the world). Laos with 853 documents, and the publication ranking of 141 from 1996 to 2011 was the last country in this region. The USA was the first country in the world with the highest number of publications (6149455), H-index (1035) and overall citation (114546415) (see Table 1).

Interestingly, Malaysia had the fewest citations per document (overall 7.64 cite per document) and the least collaboration with the world (37\%) among ASEAN countries, whereas Laos had the most international collaboration (91\%) in this region from 1996 to 2011 (see Figure 1 and Table 2). Furthermore, Malaysia and the United States had the highest self-citations with $24 \%$ and $48 \%$ of all the citations that were relieved during that period among ASEAN and the top ten countries in the world (see Table 2 and Figure 1). Moreover, Malaysia had the least collaboration with the world in the last 16 years among ASEAN countries (1996-2011). As Table 2 shows, there are significant differences among the number of documents $(\mathrm{H}(2)=138, \mathrm{p}<0.01)$, citations $(\mathrm{H}(2)$ $=140.62, \mathrm{p}<0.01)$, self-citations $(\mathrm{H}(2)=142.82, \mathrm{p}<0.01)$, and citations per document $(\mathrm{H}(2)=13.09, \mathrm{p}<0.01)$ among ASEAN countries.

Publication trends in ASEAN countries are promising in comparison with the top ten countries in the world (see Figure 2 and Table 3). There was a significant difference $(p<0.01)$ between ASEAN and developed countries in number of documents, citable documents, citations (overall), self-citations, cited documents and research collaboration with the world. The rate of growth (Figure 2) in scientific publication was $24 \%$ in Cambodia (the highest in ASEAN), while Japan had $1.4 \%$ of growth in publication among these countries.

To evaluate the relationship among related items of publication productivity and GDP and Internet usage, Spearman correlation coefficient was applied. Table 4 shows the correlation between indices and GDP and internet usage for ASEAN and the top ten countries separately. The results showed that there was a positive and significant relationship between GDP and the number of publications, citable documents, citation, self-citation and cited documents in ASEAN and the top ten countries in the world. However, one variable of international collaboration had a significant and negative relationship with GDP.

Regarding the relationship between internet usage and all the variables, we found a significant and positive relationship in ASEAN countries except for the variable of international collaboration. However, there was a positive and significant $(\mathrm{p}<0.01)$ relationship between international collaboration and internet usage in the top ten countries.

Prior to data analysis, normality test was conducted. The results revealed that all variables were not distributed normally so that we used Kruskal Wallis test, a non-parametric test, to examine publication productivity among the top ten Malaysian universities. Table 5 shows the mean and standard deviation for all types of publications among the top ten universities in Malaysia. The results of Kruskal Wallis test confirmed a significant difference among these universities. The institution with the first ranking in Malaysia was University of Malaya with 13105 publications from 1996 to 2011. The main field of research in this university was physics and astronomy with $15 \%$ of all publications. et al.,Moreover, the result of Spearman correlation coefficient test showed a positive and significant relationship among the number of articles, conference papers, reviews and letters published during these years. Except the number of conference papers and letters, all other coefficients showed a strong relationship.

Table 3. Comparison between ASEAN and the top 10 countries for publication

\begin{tabular}{cccccccc}
\hline \multirow{2}{*}{ REGION } & \multicolumn{2}{c}{ ASEAN } & \multicolumn{2}{c}{ TOP TEN COUNTRIES } & \multirow{2}{*}{ Z } & P value \\
\cline { 2 - 5 } & Mean & SD & Mean & SD & & $<0.01$ \\
Documents & 1980.0 & 3453.7 & 71558.6 & 112595.0 & -14.5 & $<0.01$ \\
Citable Documents & 1859.9 & 3263.2 & 67369.3 & 104758.0 & -14.518 & $<0.01$ \\
Citation (overall) & 15774.0 & 27026.4 & 1190700.0 & 2256220.0 & -14.9 & -14.86 & $<0.01$ \\
Self-citation & 2485.9 & 4098.7 & 446135.2 & 1079040.0 & 84267.2 & -14.748 & $<0.01$ \\
Cited Documents & 1277.8 & 2021.3 & 53836.4 & 11.2 & -10.206 & $<0.01$
\end{tabular}

To compare ASEAN countries and the top ten countries, Mann-Whitney U test was applied. The results showed significant differences for all indices 
Table 4. Spearman correlation coefficient

\begin{tabular}{clcc}
\hline REGION & Index & GDP & Internet users \\
\hline \multirow{5}{*}{ ASEAN } & Documents & $.853^{* *}$ & $.681^{* *}$ \\
& Citable Documents & $.854^{* *}$ & $.669^{* *}$ \\
& Citation (overall) & $.699^{* *}$ & $.511^{* *}$ \\
& Self-citation & $.737^{* *}$ & $.534^{* *}$ \\
& Cited Documents & $.823^{* *}$ & $.646^{* *}$ \\
& \% International Collaboration & $-.502^{* *}$ & $-.595^{* *}$ \\
\hline \multirow{5}{*}{ TOP TEN } & Documents & $.972^{* *}$ & $.201^{*}$ \\
& Citable Documents & $.973^{* *}$ & $.199^{*}$ \\
& Citation (overall) & $.757^{* *}$ & $-.224^{* *}$ \\
& Self-citation & $.780^{* *}$ & $-.165^{*}$ \\
& Cited Documents & $.940^{* *}$ & 0.121 \\
& $\%$ International Collaboration & $-.407^{* *}$ & $.557^{* *}$ \\
\hline
\end{tabular}

**. Correlation is significant at the 0.01 level (2-tailed).

*. Correlation is significant at the 0.05 level (2-tailed).

Table 5. Kruskl Wallis test was applied to examine publication productivity among the top ten Malaysian universities

\begin{tabular}{|c|c|c|c|c|c|c|c|c|}
\hline \multirow[b]{2}{*}{ university } & \multicolumn{2}{|c|}{ Article } & \multicolumn{2}{|c|}{ Conference } & \multicolumn{2}{|c|}{ Review } & \multicolumn{2}{|c|}{ Letter } \\
\hline & Mean & SD & Mean & SD & Mean & SD & Mean & SD \\
\hline University of Malaya & 638 & 618 & 125 & 152 & 32 & 34 & 9 & 6 \\
\hline Universiti Sains Malaysia & 570 & 609 & 131 & 160 & 19 & 24 & 4 & 4 \\
\hline Universiti Putra Malaysia & 570 & 645 & 114 & 143 & 20 & 24 & 1 & 2 \\
\hline Universiti Kebangsaan Malaysia & 416 & 509 & 188 & 287 & 14 & 20 & 2 & 3 \\
\hline Universiti Teknologi Malaysia & 180 & 262 & 210 & 282 & 6 & 12 & 0 & 0 \\
\hline Universiti Teknologi MARA & 103 & 153 & 150 & 281 & 4 & 7 & 0 & 1 \\
\hline $\begin{array}{l}\text { International Islamic University } \\
\text { Malaysia }\end{array}$ & 98 & 131 & 57 & 92 & 4 & 4 & 1 & 2 \\
\hline Multimedia University & 111 & 100 & 89 & 87 & 4 & 5 & 0 & 0 \\
\hline Universiti Teknologi Petronas & 51 & 98 & 85 & 155 & 2 & 4 & 0 & 0 \\
\hline Universiti Malaysia Perlis & 32 & 58 & 43 & 70 & 1 & 2 & 0 & 0 \\
\hline Chi square & \multicolumn{2}{|c|}{84} & \multicolumn{2}{|c|}{22} & \multicolumn{2}{|c|}{73} & \multicolumn{2}{|c|}{90} \\
\hline \multirow[t]{2}{*}{$P$ value } & \multicolumn{2}{|c|}{$<0.01$} & \multicolumn{2}{|c|}{$<0.01$} & \multicolumn{2}{|c|}{$<0.01$} & \multicolumn{2}{|c|}{$<0.01$} \\
\hline & \multicolumn{2}{|c|}{ Article } & \multicolumn{2}{|c|}{ Conference } & \multicolumn{2}{|c|}{ Review } & & \\
\hline Conference & \multicolumn{2}{|c|}{$.817 * *$} & & & & & & \\
\hline Review & \multicolumn{2}{|c|}{$.894 * *$} & \multicolumn{2}{|c|}{$.717 * *$} & & & & \\
\hline Letter & \multicolumn{2}{|c|}{$.746^{* *}$} & \multicolumn{2}{|c|}{$.488 * *$} & \multicolumn{2}{|c|}{$.741 * *$} & & \\
\hline
\end{tabular}

Spearman's rho Correlation Coefficients 

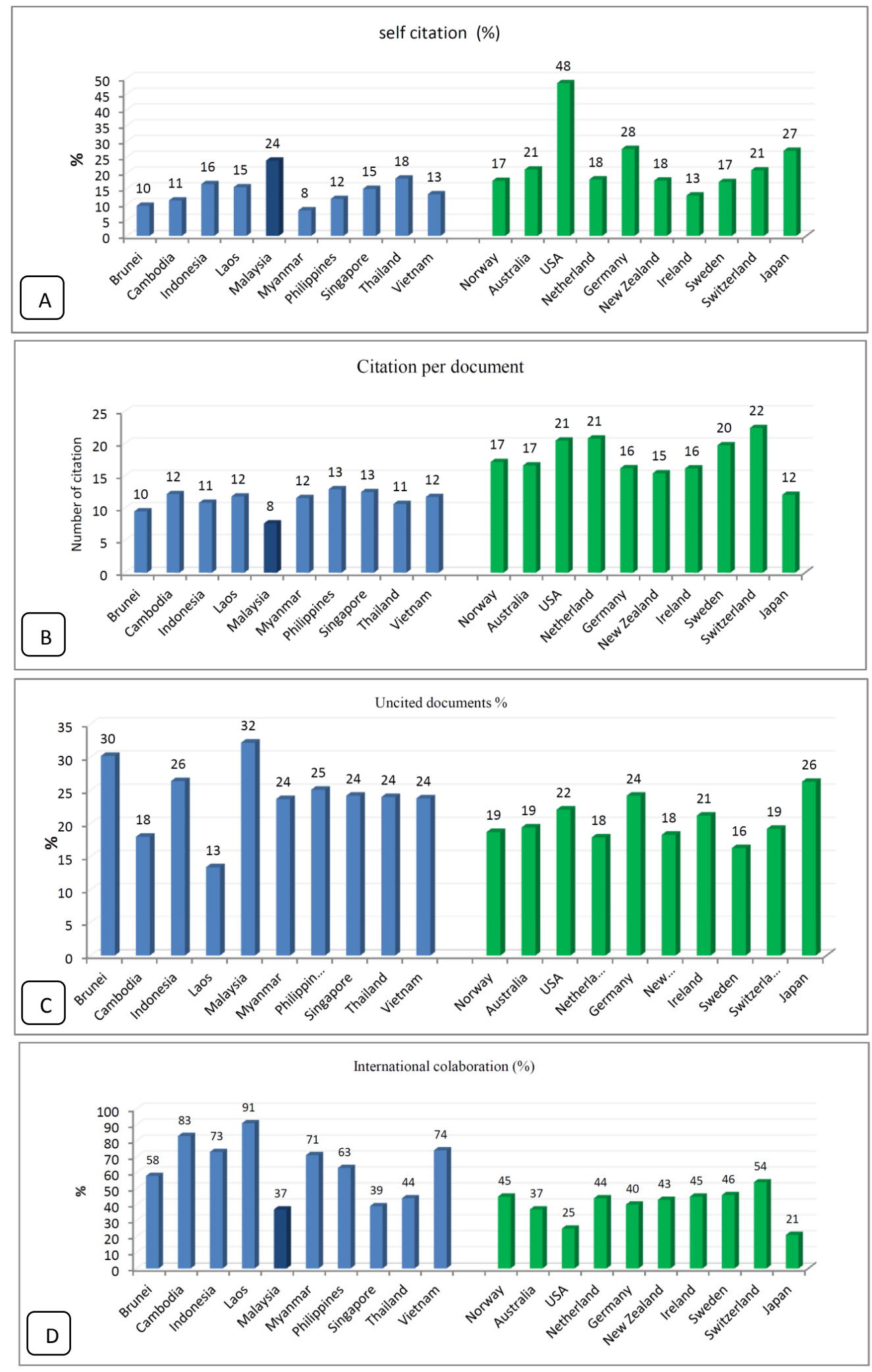

Figure 1. Comparison among ASEAN and World's Best Countries regarding self citation (A); Citation per document (B); Un-cited documents (C); and International collaboration (D) 

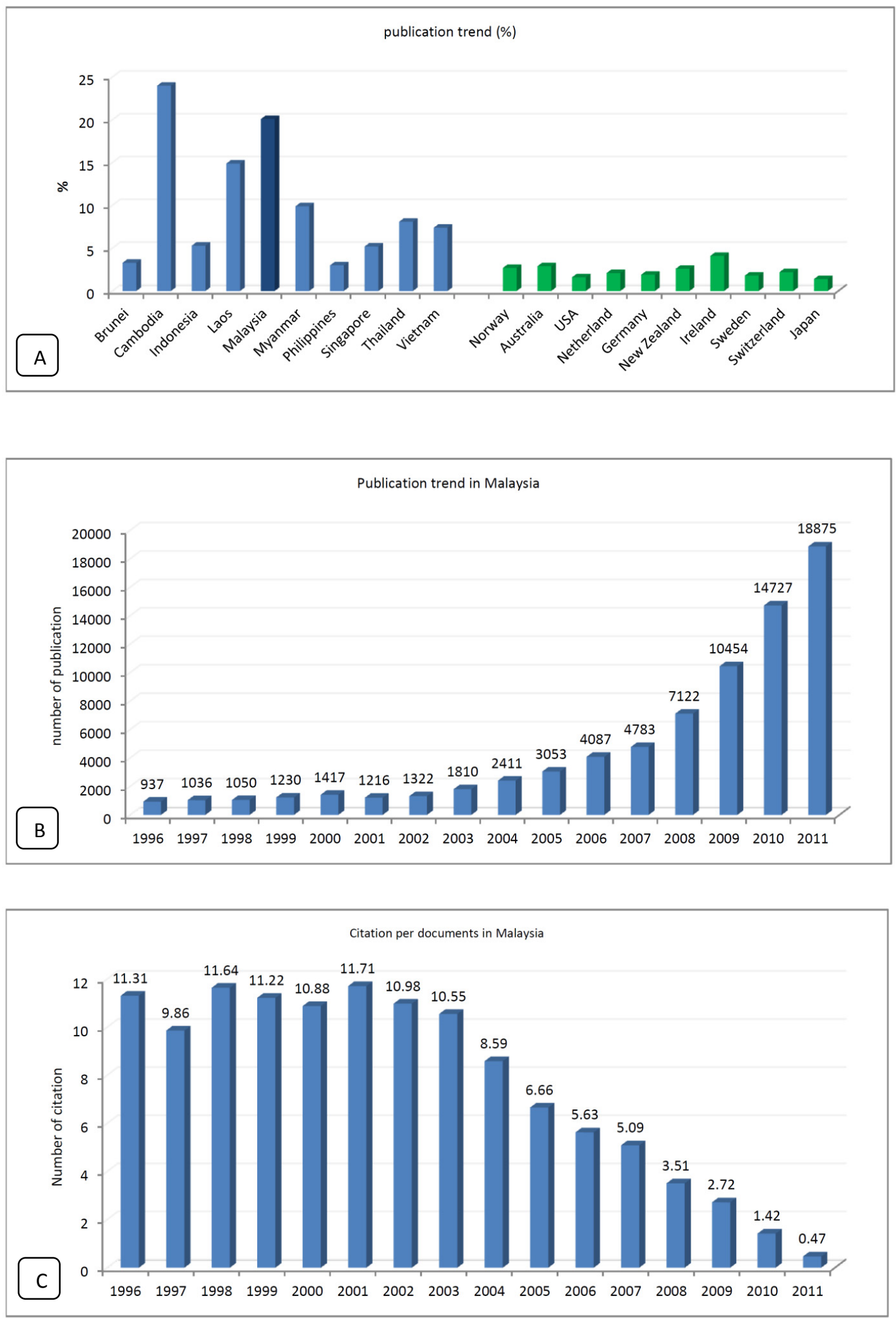

Figure 2. Publication trend in ASEAN countries and World's Best Countries (A); Publication trend in Malaysia (B); Citation per document in Malaysia (C) 


\section{Discussion and Conclusion}

In the current study, we made a comparison in Scopus database (SCImago) between ASEAN and the top 10 countries in the world regarding the relationship among economic growth, internet usage and publication productivity from 1996 to 2011. In addition, we made a comparison among the first 10 Malaysian universities.

We used SJR, or SCImago Journal and Country Rank, as a measure of the scientific prestige of scholarly sources derived from the Google Page Rank ${ }^{\mathrm{TM}}$ algorithm. It attempts to even out the differences in citation practice in different subject fields and facilitate direct comparisons of sources. Furthermore, the SCImago Journal and Country Rank portal displays journal and country scientific indicators developed from the information contained in the Scopus ${ }^{\circledR}$ database. These indicators can be used to assess and analyze scientific domains.

Publication productivity could be a good indicator of research output and used to rank countries, research institutes, or researchers in different fields (Liu \& Cheng, 2005; Meho \& Spurgin, 2005; Narin \& Hamilton, 1996; Toutkoushian et al., 2003; Yazit \& Zainab, 2007). The impact of a publication is assessed in terms of the number of citations that it has received in relation to other outputs in the journal (Yi et al., 2008). However, the number of times cited for an article is highly correlated with the length of time since its publication (Yi et al., 2008). There was a significant difference $(p<0.01)$ between citation per document (Yi et al., 2008; Calver \& Bradley 2009) in ASEAN region (11.1 citation per document) and developed countries (17.7) (see Table 3). Malaysia got $31.5 \%$ and $57.1 \%$ less citation per document in comparison with the average of citation per document in ASEAN and top ten developed countries respectively. However, Malaysia had the highest self-citation in this region with almost $24 \%$ of all citations which were received during this period. The United States had the highest number of publications as well as the highest self-citation (48\%) in the world. Malaysia had the least collaboration with the world in comparison with other ASEAN countries and it could be one of the reasons for receiving less citation per document (Ale Ebrahim et al., 2013). Based on the literature, the mean value of citation per publication of collaborative papers was higher than that of single country publications.

Publication trends in ASEAN countries with $10.1 \%$ growth are promising in comparison with the developed countries studied in our research $(2.3 \%)$. Figure 2 represents the publication trend and the number of publications in Malaysia between 1996 and 2011. The number of publications increased dramatically after 2007 with 4783 to 18875 documents in 2011 (almost 4 times). However, the number of citations decreased rapidly from 5.09 to 0.47 citations per document during these years (11times). One of the main reasons for the increase in the number of publications in Malaysia could be focusing heavily on increasing the quality of research in its research universities such as University of Malaya. Malaysia spends 1\% of its gross domestic product on development and research projects as determined in the 10th Malaysian Plan. Moreover, increasing the number of $\mathrm{PhD}$ students and changing their program from conventional dissertations to paper-based dissertations (Its requirement is publication in high peer-reviewed journals) could be another reason. The number of $\mathrm{PhD}$ students in Malaysia has increased 10 times in recent years (from about 4,000 students in 2002 to almost 40,000 in 2012). Table 5 shows the 10 first universities in Malaysia. The first top five universities have been chosen as research universities and received additional government funding. Two third (68.8\%) of all Malaysian publications have been produced by these research universities from 1996 to 2011.

Chemistry, Physics, and Astronomy are the first fields regarding the number of publications and citations. Institutes that are working in these fields could publish more papers and get more citations. Malaysian universities mostly work on Engineering and Medicine in comparison with the top universities located in the top countries such as the United States.

Our findings in this study showed a positive and significant relationship between GDP and the number of publications. This finding was similar to the previous researches that found positive and significant relationship between education and economic growth (Mankiw et al., 1992; Barro, 1991; Bils \& Klenow, 2000). Moreover, a recent research study by Jin and Jin (2013) indicated that publication productivity in different fields has dissimilar effects on economic growth. Surprisingly, for one variable i.e., international collaboration, we found that there is a significant and negative relationship between international collaboration and the GDP in ASEAN countries, while the number of people with access to the World Wide Web in developed countries had significant and positive relationship with research collaboration projects. The countries with more economic growth like the United States had less research collaboration with other counties.

Publication trends in ASEAN countries and especially in Malaysia (20.14 times increased) are encouraging in comparison with the top ten developed countries. Nevertheless, these publications could not get reasonable citations. Researchers, science managers, as well as policy makers should try to find different ways to increase citation per document (Ale Ebrahim et al., 2013) such as improving the quality and visibility of their researches 
and invest more on research studies whose outputs lead to more rapid economic growth.

\section{Acknowledgements}

The authors wish to extend their best gratitude to Mrs. Elham Sadat Yahyavi, and Mrs. Rezvan ...... for their kind assistance in this project.

\section{References}

Aghaei Chadegani, A., Salehi, H., Md Yunus, M., Farhadi, H., Fooladi, M., Farhadi, M., \& Ale Ebrahim, N. (2013). A comparison between two main academic literature collections: Web of Science and Scopus databases. Asian Social Science, 9(5), 18-26. http://dx.doi.org/10.5539/ass.v9n5p18

Ale Ebrahim, N., Salehi, H., Embi, M. A., Habibi, T. F., Gholizadeh, H., \& Motahar, S. M. (2013). Effective Strategies for Increasing Citation Frequency. International Education Studies, 6, 93-99. http://dx.doi.org/10.5539/ies.v6n11p93

Anand, S., \& Sen, A. (1994). Human development index: methodology and measurement. Human Development Report Office (HDRO), United Nations Development Programme (UNDP).

Bar-Ilan, J. (2008). Which h-index? - A comparison of WoS, Scopus and Google Scholar. Scientometrics, 74(2), 257-271. http://dx.doi.org/10.1007/s11192-008-0216-y

Barro, R. J. (1991). Economic growth in a cross section of countries. The quarterly journal of economics, 106(2), 407-443. http://dx.doi.org/10.2307/2937943

Becker, G. S. (2009). Human capital: A theoretical and empirical analysis, with special reference to education. University of Chicago Press.

Bils, M., \& Klenow, P. J. (2000). Does schooling cause growth? American economic review, 1160-1183. http://dx.doi.org/10.1257/aer.90.5.1160

Braun, T., Glänzel, W., \& Schubert, A. (2006). A Hirsch-type index for journals. Scientometrics, 69(1), 169-173. http://dx.doi.org/10.1007/s11192-006-0147-4

Brown, L. D., \& Gardner, J. C. (1985). Using citation analysis to assess the impact of journals and articles on contemporary accounting research (CAR). Journal of Accounting Research, 23(1), 84-109. http://dx.doi.org/10.2307/2490908

Calver, M. C., \& Bradley, J. S. (2009). Should we use the mean citations per paper to summarise a journal's impact or to rank journals in the same field? Scientometrics, 81(3), 611-615. http://dx.doi.org/10.1007/s11192-008-2229-y

Falagas, M. E., Pitsouni, E. I., Malietzis, G. A., \& Pappas, G. (2008). Comparison of PubMed, Scopus, web of science, and Google scholar: strengths and weaknesses. The FASEB Journal, 22(2), 338-342. http://dx.doi.org/10.1096/fj.07-9492LSF

Fooladi, M., Salehi, H., Md Yunus, M., Farhadi, M., Aghaei Chadegani, A., Farhadi, H., \& Ale Ebrahim, N. (2013). Does Criticisms Overcome the Praises of Journal Impact Factor? Asian Social Science, 9(5), 176-182. http://dx.doi.org/10.5539/ass.v9n5p176

Fox, M. F. (1983). Publication productivity among scientists: A critical review. Social Studies of Science, 13(2), 285-305. http://dx.doi.org/10.1177/030631283013002005

Gu, Y., \& Zainab, A. N. (2001). Publication productivity of Malaysian researchers in the field of Computer Science and Information Technology. Malaysian Journal of Library \& Information Science, 6(1), 1-23.

Hart, R. L. (2000). Co-authorship in the academic library literature: a survey of attitudes and behaviors. The Journal of Academic Librarianship, 26(5), 339-345. http://dx.doi.org/10.1016/S0099-1333(00)00140-3

Heeks, R., \& Bailur, S. (2007). Analyzing e-government research: Perspectives, philosophies, theories, methods, and practice. Government Information Quarterly, 24(2), 243-265. http://dx.doi.org/10.1016/j.giq.2006.06.005

Jin, J. C., \& Jin, L. (2013). Research publications and economic growth: evidence from cross-country regressions. Applied Economics, 45(8), 983-990. http://dx.doi.org/10.1080/00036846.2011.613785

Joynt, R. L., \& Leonard, J. A. (1980). Dantrolene sodium suspension in treatment of spastic cerebral palsy. $\begin{array}{lllll}\text { Developmental Medicine } \& \text { Child } & \text { Neurology, } & 22(6), & \text { 755-767. }\end{array}$ http://dx.doi.org/10.1111/j.1469-8749.1980.tb03742.x 
Kelly, J. C., Glynn, R. W., O'Briain, D. E., Felle, P., \& McCabe, J. P. (2010). The 100 classic papers of orthopaedic surgery a bibliometric analysis. Journal of Bone \& Joint Surgery, British Volume, 92(10), 1338-1343. http://dx.doi.org/10.1302/0301-620X.92B10.24867

Lefaivre, K. A., \& O'Brien, P. J. (2011). 100 most cited articles in orthopaedic surgery. Clinical Orthopaedics and Related Research ${ }^{\circledR}, 469(5), 1487-1497$. http://dx.doi.org/10.1007/s11999-010-1604-1

Liu, N. C., \& Cheng, Y. (2005). The academic ranking of world universities. Higher education in Europe, 30(2), 127-136. http://dx.doi.org/10.1080/03797720500260116

Lucas Jr, R. E. (1988). On the mechanics of economic development. Journal of monetary economics, 22(1), 3-42. http://dx.doi.org/10.1016/0304-3932(88)90168-7

Mankiw, N. G., Romer, D., \& Weil, D. N. (1992). A contribution to the empirics of economic growth. The quarterly journal of economics, 107(2), 407-437. http://dx.doi.org/10.2307/2118477

Meho, L. I., \& Spurgin, K. M. (2005). Ranking the research productivity of library and information science faculty and schools: An evaluation of data sources and research methods. Journal of the American Society for Information Science and Technology, 56(12), 1314-1331. http://dx.doi.org/10.1002/asi.20227

Meho, L. I., \& Yang, K. (2007). Impact of data sources on citation counts and rankings of LIS faculty: Web of Science versus Scopus and Google Scholar. Journal of the American Society for Information Science and Technology, 58(13), 2105-2125. http://dx.doi.org/10.1002/asi.20677

Narin, F., \& Hamilton, K. S. (1996). Bibliometric performance measures. Scientometrics, 36(3), 293-310. http://dx.doi.org/10.1007/BF02129596

Nelson, R. R., \& Phelps, E. S. (1966). Investment in humans, technological diffusion, and economic growth. The American Economic Review, 69-75.

Ponce, F. A., \& Lozano, A. M. (2010). Highly cited works in neurosurgery. Part I: the 100 top-cited papers in neurosurgical journals: A review. Journal of Neurosurgery, 112(2), 223-232. http://dx.doi.org/10.3171/2009.12.JNS091599

Romer, P. M. (1990). Endogenous technological change. Journal of Political Economy, S71-S102. http://dx.doi.org/10.1086/261725

Sarel, M. (1997). Growth and productivity in ASEAN countries: International Monetary Fund.

Schubert, A., \& Glänzel, W. (2007). A systematic analysis of Hirsch-type indices for journals. Journal of Informetrics, 1(3), 179-184. http://dx.doi.org/10.1016/j.joi.2006.12.002

Toutkoushian, R. K., Porter, S. R., Danielson, C., \& Hollis, P. R. (2003). Using publications counts to measure an institution's research productivity. Research in Higher Education, 44(2), 121-148. http://dx.doi.org/10.1023/A:1022070227966

Uzun, A. (2002). Productivity ratings of institutions based on publication in Scientometrics, Informetrics, and Bibliometrics, 1981-2000. Scientometrics, 53(3), 297-307. http://dx.doi.org/10.1023/A:1014864827441

Yazit, N., \& Zainab, A. N. (2007). Publication productivity of Malaysian authors and institutions in LIS. Malaysian Journal of Library and Information Science, 12.

Yi, H., Ao, X., \& Ho, Y. S. (2008). Use of citation per publication as an indicator to evaluate pentachlorophenol research. Scientometrics, 75(1), 67-80. http://dx.doi.org/10.1007/s11192-007-1849-y

Zain, Z. M., Ishak, R., \& Ghani, E. K. (2009). The influence of corporate culture on organisational commitment: A study on a Malaysian listed company. European Journal of Economics, Finance and Administrative Sciences, 17(17), 16-26.

\section{Copyrights}

Copyright for this article is retained by the author(s), with first publication rights granted to the journal.

This is an open-access article distributed under the terms and conditions of the Creative Commons Attribution license (http://creativecommons.org/licenses/by/3.0/). 